\title{
Statistical Modelling of Body Weight and Linear Body Measurements in Nigerian Indigenous Chicken
}

\author{
${ }^{1}$ Ukwu, H.O., ${ }^{2}$ Okoro, V.M.O., and Nosike R.J. ${ }^{3}$ \\ Department of Animal Breeding and Physiology, College of Animal science,University of Agriculture Makurdi, \\ P.M.B. 7267 Makurdi, Benue State, Nigeria. \\ Department of Animal Science, Federal University of Technology Owerri, Imo State, Nigeria \\ Department of Animal Breeding and Physiology, Michael Okpara University of Agriculture Umudike, Nigeria
}

\begin{abstract}
This study was conducted to determine the relationship between body weight and linear body parameters in the Nigerian indigenous chickens, and to establish equations for predicting body weight of local chickens using linear body measurements. A total of forty female local chickens were used for the experiment. The birds were managed intensively for a month before measurements were taken from each bird. Body weight was measured using weighing balance. Linear body parameters - shank length, wing length, thigh length, body girth and back length, were measured using a tailor's tape. Data were analyzed using Statistical package for the Social Sciences (SPSS) version 17.0. The correlations between body weight and linear body measurements were determined using Pearson's product moment correlation coefficient ( $r$ ). Data were also subjected to simple and multiple linear regression analysis. Correlations between body weight and the linear body measurements (shank length, body girth, wing length, thigh length and back length) were high, positive and significant $(P<0.01)$. The values of the coefficients of determination $\left(R^{2}\right)$ ranged from 0.659 to 0.802 , with shank length showing the highest $R^{2}$ value. This implies that shank length could be the best predictor of body weight of Nigerian local chickens. The predictive equations showed that there were significant $(P<0.01)$ relationships between body weight and linear body measurements. High $R^{2}$ values observed in this study shows that the predictive equations could be used to predict body weight accurately, with the multiple regression model being more efficient than the simple regression models.
\end{abstract}

Keywords: Chicken, parameters, prediction, statistical model, regression

\section{Introduction}

A number of conformation traits are known to be good indicators of body growth and market value of chickens apart from body weight. Poultry breeders have tried to establish the relationship that exist between body weight and linear body parameters such as shank length, breast width, keel length, neck length, back length and thigh length. The relationship existing among linear body parameters provides useful information on the performance and carcass value of animals. Relationships between body weight and linear body measurements are important for predicting body weight and can also be applied speedily in selection and breeding programmes. The use of body measurements to predict body weight of different animal species (e.g. cattle, sheep and goat) have been done by some authors (e.g. Attah et al., 2004; Sowande and Sobola, 2007; Goe, 2007). However, there is little information on the prediction of body weight of chickens using linear body measurements (e.g. Momoh and Kershima, 2008).

The objective of this study was to determine the relationship between body weight and linear body measurements in Nigerian local chickens; and to model the relationship between body weight and linear body measurement in Nigerian local chickens.

\section{Materials and Methods}

The experiment was conducted at Poultry Teaching and Research Farm of University of Agriculture Makurdi, Benue State, Nigeria. Benue state is located at the North-central part of Nigeria. The area is characterized by a period of dry season from October to March, and a period of rainy season from April to September. Annual rainfall ranges from $973 \mathrm{~mm}$ to $1324 \mathrm{~mm}$. A total of forty mature female local chickens of Nigeria, already in lay were used for the experiment. The birds were de-wormed and allowed to stabilize for one month before data collection. They were housed in deep litter pens and fed commercial layers mash containing $17.0 \%$ crude protein, $4.0 \%$ Crude fat, $5.0 \%$ Crude fibre, $12.9 \%$ Crude ash, 3.8\% Calcium and other nutrients. Water was also provided ad libitum through the experimental period. Body weight of individual birds was measured using weighing balance with accuracy of $0.1 \mathrm{~kg}$. The following linear body measurements were recorded using a tailor's tape: shank length (SL), body girth (BG), wing length (WL), back length (BL) and thigh length (TL). The linear body measurements were taken as described by Fayeye et al. (2006). The measurements were as described below. 
Shank length: length of the tarso-metatarsus from the hock joint to the metatarsal pad,

Wing length: length of the wing from the scapula joints to the last digit of the wing,

Body girth: the circumference of the breast region,

Back length: length between the base of the neck and the uropygial gland,

Thigh length: length between the hock joint and the pelvic joint (Molenaar et al., 2008)

Statistical analysis of data collected from the experiment was performed using Statistical package for the social sciences (SPSS) version 17.0. The relationship among body weight and linear body measurements was determined using Pearson's product moment correlation coefficient (r). Linear regression of the linear body parameters on body weight was also performed using the following simple and multiple linear regression models:

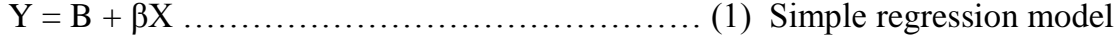

$$
\begin{aligned}
& \mathrm{Y}=\mathrm{B}+\beta_{1} \mathrm{X}_{1}+\beta_{2} \mathrm{X}_{2}+\ldots+\beta_{\mathrm{k}} \mathrm{X}_{\mathrm{k}} \ldots \ldots \ldots \ldots \ldots \ldots . \text { (2) Multiple regression model }
\end{aligned}
$$

Where $\mathrm{Y}=$ dependent variable (body weight)

$\mathrm{Xs}=$ independent variables $(\mathrm{SL}, \mathrm{BG}, \mathrm{WL}, \mathrm{TL}, \mathrm{BL})$

$\mathrm{B}=$ the intercept

$\beta \mathrm{s}=$ the slopes

\section{Results and Discussion}

The means and standard error of the means of body weight and linear body parameters are shown in Table 1. Table 2 shows the correlations between body weight and linear body measurements of Nigerian local chickens. The equations for predicting body weight using linear body measurements are shown in Table 3 .

Body weight ranged between $1.30 \mathrm{~kg}$ and $1.60 \mathrm{~kg}$ with a mean of $1.45 \mathrm{~kg}$. The mean body weight observed in this study was higher than the value (1.06kg) reported by Momoh and Kershima (2008) for female local chickens in Makurdi area of Benue state. This difference could be attributed to age, and their measurements were taken from female local chickens on free range, while birds used in this study were managed intensively.

Shank length ranged between $8.10 \mathrm{~cm}$ and $9.20 \mathrm{~cm}$ with a mean of $8.58 \mathrm{~cm}$. The mean shank length was higher than the value $(6.60 \mathrm{~cm})$ reported by Momoh and Kershima (2008) for female local chickens.

Body girth ranged between $26.20 \mathrm{~cm}$ and $27.50 \mathrm{~cm}$. The mean body girth was $26.75 \mathrm{~cm}$. This value was in the same range with the values $(26.7 \mathrm{~cm}, 26.9 \mathrm{~cm}$, and $27.5 \mathrm{~cm})$ reported by Fayeye et al., (2006) for frizzle, naked neck and normal feathered local chickens of Nigeria, respectively.

Wing length ranged between $17.40 \mathrm{~cm}$ and $18.40 \mathrm{~cm}$, with a mean of $17.82 \mathrm{~cm}$. This value was close to the values $(17.5 \mathrm{~cm}, 17.8 \mathrm{~cm}$, and $17.7 \mathrm{~cm})$ reported by Fayeye et al., (2006) for naked neck, frizzle and normal feathered Nigerian local chicken.

Thigh length ranged between $18.30 \mathrm{~cm}$ and $19.50 \mathrm{~cm}$. The mean value of thigh length observed in this study was $18.95 \mathrm{~cm}$. Back length ranged between $21.50 \mathrm{~cm}$ and $22.10 \mathrm{~cm}$. The mean value of back length observed in this study was $21.82 \mathrm{~cm}$.

Correlations between body weight and shank length, body girth, wing length, thigh length, and back length were $0.896,0.816,0.812,0.839$, and 0.888 respectively. All the correlations were high, positive and significant $(\mathrm{P}<0.01)$. This implies that there exist a strong linear relationship between body weight and shank length, body girth, wing length, thigh length and back length. This result suggests that an improvement in body weight of Nigerian local chickens would lead to an improvement in linear body parameters. A similar result was reported by Momoh and Kershima (2008) using Nigerian local chickens. This result also corroborates the reports of Yahaya et al., (2012), and Alabi et al., (2012) that high positive correlation exist between body weight and linear body measurements in broilers and naked neck/venda chickens of South Africa, respectively.

Correlations among the linear body measurements (shank length, wing length, body girth, thigh length and back length) were high, positive and significant $(\mathrm{P}<0.01)$. This result was in line with the report of Yahaya et al., (2012) using Hubbard and Arboracre broiler strains.

Prediction equations relating body weight and linear body measurements in Nigerian local chickens are shown in Table 3. Body weight and linear body measurements had significant $(\mathrm{P}<0.01)$ associations. The values of the coefficients of determination $\left(R^{2}\right)$ ranged from 0.659 to 0.802 , with shank length showing the highest $R^{2}$ value. This implies that shank length could be the best predictor of body weight of Nigerian local chickens.

Multiple linear regression model relating body weight and linear body measurements of Nigerian local chickens is shown below:

$$
\hat{\mathrm{Y}}=-7.606+0.152 \mathrm{SL}+0.057 \mathrm{BG}+0.052 \mathrm{WL}+0.026 \mathrm{TL}+0.221 \mathrm{BL}
$$

Where $\hat{Y}$ is the estimated body weight. 
The $\mathrm{R}^{2}$ value for multiple regressions in this study was 0.934 . The predictive equations showed that there were significant relationships between body weight and linear body measurements. High $\mathrm{R}^{2}$ values observed in this study shows that the predictive equations could be used to predict body weight accurately, with the multiple regression models being more efficient than the simple regression models. $\mathrm{R}^{2}$ values obtained in this study were higher than those reported by Momoh and kershima (2008) for Nigerian local chickens reared on free range.

\section{Tables}

Table 1. Descriptive statistics of body weight and linear body measurements of Nigerian local chicken hens

\begin{tabular}{llccrl}
\hline Parameter & N & Minimum & Maximum & Mean & SEM \\
\hline BW $(\mathrm{kg})$ & 40 & 1.30 & 1.60 & 1.45 & 0.0184 \\
SL $(\mathrm{cm})$ & 40 & 8.10 & 9.20 & 8.58 & 0.0441 \\
BG $(\mathrm{cm})$ & 40 & 26.20 & 27.50 & 26.75 & 0.0563 \\
WL $(\mathrm{cm})$ & 40 & 17.40 & 18.40 & 17.82 & 0.0501 \\
TL $(\mathrm{cm})$ & 40 & 18.30 & 19.50 & 18.95 & 0.0554 \\
BL $(\mathrm{cm})$ & 40 & 21.50 & 22.10 & 21.82 & 0.0269 \\
\hline
\end{tabular}

Table 2. Correlations between body weight and linear body measurements of Nigerian local chicken hens

\begin{tabular}{lllllll}
\hline & BW & SL & BG & WL & TL & BL \\
\hline BW & - & & & & & \\
SL & 0.896 & - & & & & \\
BG & 0.816 & 0.763 & - & & & \\
WL & 0.812 & 0.719 & 0.635 & - & - & - \\
TL & 0.839 & 0.720 & 0.650 & 0.774 & 0.858 & - \\
BL & 0.888 & 0.750 & 0.698 & 0.740 &
\end{tabular}

Correlations were significant at $P<0.01$

Table 3. Predictive equations relating body weight to linear body measurements of Nigerian local chicken hens.

\begin{tabular}{llccc}
\hline Parameters & Predictive equations & SE & $\mathrm{R}^{2}$ & LS \\
\hline SL & $\hat{Y}=-1.757+0.374 \mathrm{SL}$ & 0.0456 & 0.802 & $* *$ \\
BG & $\hat{Y}=-5.695+0.267 \mathrm{BG}$ & 0.0593 & 0.666 & $* *$ \\
WL & $\hat{Y}=-3.863+0.298 \mathrm{WL}$ & 0.0599 & 0.659 & $* *$ \\
TL & $\hat{Y}=-3.828+0.278 \mathrm{TL}$ & 0.0559 & 0.704 & $* *$ \\
BL & $\hat{Y}=-11.826+0.608 \mathrm{BL}$ & 0.0472 & 0.789 & $* *$ \\
\hline
\end{tabular}

** $(\mathrm{P}<0.01) ; \mathrm{LS}=$ level of significance; $\mathrm{SE}=$ standard error; $\mathrm{R}^{2}=$ coefficient of determination

\section{Conclusion and Recommendation}

The results of this study suggest that there are high positive correlations between body weight and linear body measurements. The implication is that an improvement in body weight could lead to an improvement in linear body measurements. This relationship may be used in selection programme for genetic improvement of Nigerian local chickens. The study also revealed that body weight could be predicted, with high degree of accuracy, using linear body measurements.

Since body weight can be predicted efficiently using linear body measurements, it is recommended that in areas, especially rural areas, where weighing balance or scale may not be readily available, a tailor's tape can be used to measure linear body parameters and thereafter used to estimate body weight of Nigerian local chickens from the predictive equations.

\section{References}

[1] O.J. Alabi, J.W. Ng'ambi, D. Norris, and S.S.A. Egena, (2012) Comparative Study of Three Indigenous Chicken Breeds of South Africa: body Weight and Linear body measurements. Agricultural Journal 7(3): $220-225$

[2] S. Attah, A.O. Okubanjo, A.B. Omojola, and A.O. Adesehinwa, (2004) Body and carcass linear measurements of goats slaughtered at different weights. Livestock Research for Rural Development 16(8)

[3] T.R. Fayeye, K.L. Ayrinde, V. Ojo and O.M. Adesina, (2006) frequency and influence of some major genes on body weight and body size parameters of Nigerian local chickens. Livestock Research for Rural Dev. 18(3)

[4] M. Goe, (2007) Use of heart girth to predict body weight of working oxen in the Ethiopian highlands. Livestock production science 69: $187-195$

[5] R. Molenaar, I.A.M. Reijrink, R. Meijerhof and H. Van Den Brand (2008) Relationship between hatchling length and weight of later productive performance in broilers. World's poultry Sci. J. 64(4): $599-603$

[6] O.M. Momoh and D.E. Kershima, (2008) Linear body measurements as predictors of body weight in Nigerian local chickens. Asset series A 8(2): $206-212$

[7] V.E. Olori, (1994) Quantitative variation in the Nigerian local chicken: juvenile growth characteristics. In Proc. $5^{\text {th }}$ World congress on genetics applied to livestock production. 20: $417-420$ 
[8] J.A. Oluyemi, (1990) Germplasm component of rural poultry development in Africa. In: Proc. of International workshop on rural poultry development in Africa, held at the Obafemi Awolowo University Ile-Ife, $13-16^{\text {th }}$ Nov. 1989 Pp. $49-55$

[9] J.A. Oluyemi and F.A. Robert, (2000) Poultry production in warm wet climates. Spectrum Books Ltd, Ibadan, Nigeria.

[10] E.B. Sonaiya, and V.E. Olori (1990) Village chicken production in south western Nigerian. In Proc. of an international workshop on rural poultry development in Africa, held at the Obafemi Awolowo University Ile-Ife, 13 - $16^{\text {th }}$ Nov. 1989 Pp. $243-247$.

[11] E.B. Sonaiya, I.K. Odubote, R. Baelman, F. Demey, K. Wimmers, A. Vallezarate and P. Horst (1998) Evaluation of Nigerian local poultry ecotypes for genetic variation, disease resistance and productivity. Proc. of Silver Anniversary Conference of NSAP, Abeokuta. P316

[12] S.O. Sowande and O.S. Sobola, (2007) Body measurements of West African Dwarf Sheep as parameters estimation of live weight. Tropical Animal Health and Production. Abstract.

[13] K.W. Washburn, E. El-Gendy and D.E. Eberhart (1992) Influence of body weight on response to a heat stress environment. Proc. XIX World's poultry congress, Amsterdam, Pp53-56

[14] H.K. Yahaya, H. Ibrahim and S. Abdusalam (2012) Correlation between body weight and body conformation of two broiler strains under the same dietary treatment. Int. J. Animal and Veterinary Advances 4(3):181 - 183

[15] A. Yakubu, D.M. Ogah, and R.E. Barde, (2008) Productivity and egg quality characteristics of free range naked neck and normal feathered Nigerian indigenous chickens. Int. J. Poult. Sci. 7(6): $579-585$

[16] F. Yunis and A. Cahaner (1994). The effect of the frizzle (F) and the naked (Na) genes and their interaction on broiler at normal and high ambient temperature. $5^{\text {th }}$ World congress on genetics applied to livestock production. 